out' all new leaf primordia without injury to the apical meristem. The apical region was then protected by means of moist cotton-wool and the piece of shoot placed in peat. New leaf primordia were similarly destroyed at weekly or fortnightly intervals. New roots were abundantly formed and some pieces of material were kept alive and in a state of growth for several months, until, in fact, the material was fixed for sectioning.

Transverse serial sections from the apex downwards showed the apical meristem to be still intact and apparently normal, and every stage between complete solenostely and the normal dictyostelic condition of the older region of the shoot was observed (Figs. 1 and 2). Thus where a succession of leaf primordia had been destroyed immediately after their inception, a complete, uninterrupted vascular ring was to be observed; but where a primordium was rather older before it was destroyed, leaf-gaps of small size were present.

A full account of these observations will bə given elsewhere.

Department of Cryptogamic Botany,

$$
\text { C. W. Wardlaw. }
$$

University of Manchester. Feb. 29.

\section{Vernalization of Rice by Short Days}

VERNALIZATION by light or the treatment of seedlings to exposures of different light periods in order to accelerate flowering has been effected in temperate cereals. Cailahjan ${ }^{1}$ vernalized several varieties of winter wheat and winter rye by continuous light when low temperature had no effect on flowering. Purvis and Gregory ${ }^{2}$ have shown vernalization of winter rye both by low temperature and by short days of ten hours. These results indicate the use of light periods for vernalizing cereals which do not respond to Lysenko's method of low-temperature treatment.

Experiments performed by me have shown that vernalization of rice by chilling $\left(3^{\circ}-6^{\circ}\right.$ C. $)$ produces no significant earliness, while treatment of young seedlings by exposures to short days accelerates earemergence and increases growth-rate and grain-vield. Seven days old seedlings of a winter variety, 'Bhasamanik', were exposed to eight and ten hours of daylight for varying periods up to six weeks in the seed bed, then the seedlings were transplanted in pots and grown in the field under natural long days. In another experiment short days were given to seedlings in seed bed and continued after transplantation until the ear-emergence was noted in the individual plants. The control plants were exposed all through to normal daylight. Of the seed bed treatments for varying periods an exposure to short days for six weeks duration induces the maximum earliness and grain yield. The results are presented in the accompanying table and the ear-emergence in the treated plants is illustrated in the photograph.

\begin{tabular}{|c|c|c|c|}
\hline \multicolumn{2}{|c|}{ Treatment } & \multirow[b]{2}{*}{$\begin{array}{c}\text { Earliness in days } \\
\text { (Mean of } 15 \text { plants) }\end{array}$} & \multirow{2}{*}{$\begin{array}{l}\text { Percentage increase } \\
\text { of grain yield over } \\
\text { the controls } \\
\text { (Mean of } 15 \text { plants) }\end{array}$} \\
\hline & $\begin{array}{l}\text { Short } \\
\text { days in } \\
\text { hours }\end{array}$ & & \\
\hline $\begin{array}{l}\text { Seed bed for } \\
6 \text { weeks }\end{array}$ & $\begin{array}{r}8 \\
10\end{array}$ & $\begin{array}{l}10 \cdot 3 \\
12 \cdot 5\end{array}$ & $\begin{array}{l}16 \\
10\end{array}$ \\
\hline $\begin{array}{l}\text { Prolonged } \\
\text { until } \mathrm{far} \\
\text { emergence }\end{array}$ & $\begin{array}{r}8 \\
10\end{array}$ & $\frac{25}{26 \cdot 5}$ & $\begin{array}{l}35 \cdot 3 \\
18 \cdot 3\end{array}$ \\
\hline
\end{tabular}

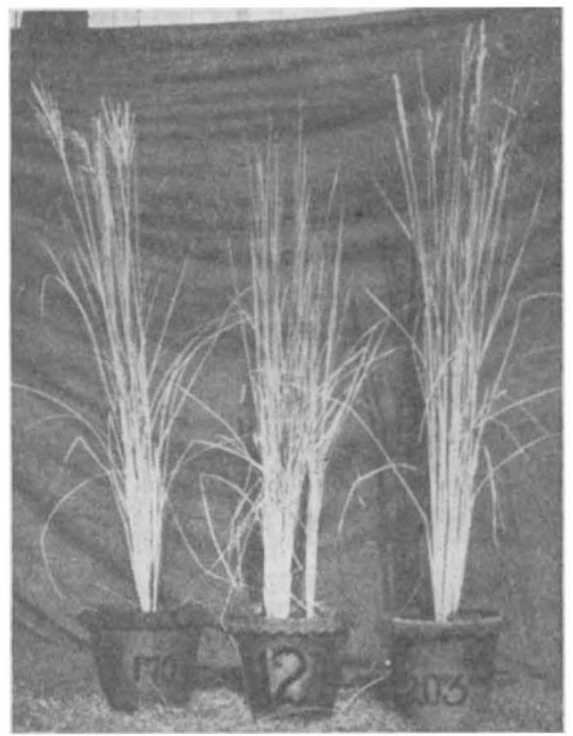

Although greater earliness and yield is obtained by the prolonged treatments, the application of the method in field practices is possible only by the treatment of seedlings in the seed bed. This method of inducing earliness and increased yield is of agricultural importance for the variety of rice grown after transplantation.

A detailed report of the work will be published elsewhere.

I desire to thank Prof. S. P. Agharkar for the facilities to carry out this investigation.

Botany Department,

S. M. Sircar.

University, Calcutta. Jan. 28.

${ }^{1}$ Cailahjan, M. Ch., Review in the Imp. Bur. Plant Gen., Bull. 17 2 Purvis, O. N., and Gregory, F. G., Ann. Bot., N.S. 1 (1937).

\section{Excretions, Ecology and Evolution}

Prof. E. J. SAlISBURY's important remarks on the probable significance of excretions in biological competition $^{1}$ should not need emphasis, although the work of Pickering ${ }^{2}$ in 1917 provides yet another reference regarding the excretions of roots. It is to be hoped that the present interest in penicillin may attract the attention of biologists to what appears in reality to be another aspect of that great field of biological study which embraces chemical morphogenesis, endocrinology and, as is now emphasized, ecological and evolutionary succession. In each of these the production of metabolites plays a part in the mediation of subsequent events.

While working under Prof. A. C. Hardy at the time when he was developing his theory of 'animal exclusion' ${ }^{3}$, I became interested in such relationships in the sea. Having in mind the striking collection of references collected by Alle ${ }^{4,5}$, I was later led to suggest ${ }^{6}$ that these 'exclusive' processes might not only be comparable with others in which the excretions of one form were found to be harmful in some instances, but also with those in which the effects of excretions appear to be beneficial at least to some section of the community. The suggestion was made that such processes may, through the continued 